\title{
Performance and Management of Political Leadership in Totalitarian and Democratic Societies
}

\author{
The Soviet Union, Germany and the United States in 1936
}

\author{
Kirill Postoutenko
}

The political leaders discussed in this paper are Joseph Stalin, Adolf Hitler and Franklin Delano Roosevelt. Their choice was dictated by a combination of similarities and differences favorable for comparison: while all the three were chief executives in their respective countries between 1936 and 1943 (the period of observation), the first two lead the totalitarian states and the latter presided over a democratic country. An inquiry into the discursive performance of political leadership in Soviet Union, Nazi Germany and the United States of America could be the first step in comparing the performance of social power in authoritarian and non-authoritarian states.

But even this first step would be too large for a short paper. Hence I would like to discuss and evaluate specifically the $\mathrm{myth} \mathrm{s}$ of " a c tive" and "omnipresent" leadership in a totali$\mathrm{t}$ a r i a n s t a t e, generated by Soviet and German propagandists and taken at a face value by many historians, sociologists, political scientists and linguists. Those myths have grown in different countries and on the opposite ends of communication networks: the leader's activity was primarily articulated by Hitler in his speeches, whereas the leader's omnipresence has been staged by the amount of references to Stalin in Soviet public sphere. In particular, Adolf Hitler and some other Nazi functionaries have frequently used in their texts the metaphors of activity and 
speed, mobility and movement (including movement for its own sake), action and dynamics (Bork 1970: 19; Faye 1987: 66-67; Voigt 1987: 64; Maas 1989: 181; Weiss 2003: 319-320; Young 1991: 81-83). Significantly, the Nazi activist language was not shared by Joseph Goebbels-Hitler's de facto PR agent and a prominent public figure (Betz 1955: 792): it seems likely that this difference, favorable for Hitler, was not quite accidental. Joseph Stalin, in his turn, stood out of the bland communication landscape of pre-war Soviet Union by the sheer number of his iconic and symbolic appearances, including posters (at least 500,000 during his reign), books (16,500,000 in 1934 alone), postcards (10,000,000 of just one press photo taken in 1929), portraits in shop windows (2:1 in relation to Lenin at one of the main Moscow streets in 1933) and repetitions of his name in Pravda editorials (at least four times in each column between 1938 and 1951) (Alekseev 1982: 8, 114-118; Tucker 1992: 160; Sartorti 1995: 195; Overy 2004; Brandenberger 2005: 253). ${ }^{1}$ This is not to say that the images of the "active" and the "omnipresent" leader never overlapped: both Hitler and Stalin were called "ceaseless workers" in press reports, title was endlessly reverberated across the media spectrum in no less than eighteen morphological innovations such as Führergrundsatz, Führerprinzip etc., and, after all, every second issue of Völkischer Beobachter was decorated with the Nazi leader's portrait (Berning 1964: 82-84; Brackman 1988: 77-78; Herz 1995: 52). However, the differentiation between highlighting action and orchestrating ubiquity was quite apparent, and it is supported by secondary linguistic and historical observations: for example, Hitler was not only admiring activity, but clearly placed the action ("fight for the worldview") above interaction ("speaking" and "bargaining" parliaments), while Stalin has proved his omnipresence by intervening in secondary affairs far away from his competence (such as arts and sciences) (Rigby 1977: 61; Werth 1999: 40).

As valuable as this information is, it is not immediately related to Stalin's or Hitler's performance of political leadership, and so far it does not give us any clue as to how their self-centered discursive identities functioned in public sphere. On the one hand, Hitler's talking about activity does not necessarily mean his being active by means of talk. On the other hand, millions of books with Stalin's name on a cover turn

1| The similar correlation between horizontal and vertical circulation of iconic references to the leader is noticeable in Italian context,where the postcards and magazine covers depicting the leader were in the 1920s-1930s even more ubiquitous than in Stalin's Russia (Falasca-Zamponi 2004: 94). 
him into a high priority of a state publishing industry-in the same league as Alexander Pushkin who also had some 18,000,000 of his books published in 1934-1937 (Friedberg 1962: 195)—but fail to speak for his strategy of self-legitimation. Besides, it seems rather pointless to discuss any features of totalitarianism without comparing them to the non-totalitarian environment: some similarities between Stalin's and Hitler's political performance may well be, say, the common places of power self-representation in the $20^{\text {th }}$ century. Hence, to give credible answers to the question "How the myths of leaders' a c t $i v$ ity and o $m$ n i p rese n ce in a totalitarian state are related to their actual discursive performance of political power?" one has to take into account not only the crucial social dichotomy between the semantics of firstperson narration and the pragmatics of self-performance, but also three sets of secondary distinctions:

between the modes of orientation: "egocentric" (1) vs. "objective" (2): tell the right thing here

(2) President explains New Deal at the Senate hearings

between the communicative roles: "self (first person)" (1) vs. "other (third person)"(2):

(1) [Stalin's speech:] I

(2) [Pravda report:] send my greetings to the workers of Donetsk basin

Stalin sends his greetings to the workers of Donetsk basin

between the political systems: "totalitarian" (1-2) vs. "non-totalitarian" (3):

(1) Soviet Union

(2) Nazi Germany

(3) United States of America.

The materials collected and analyzed for this project address the aforementioned oppositions at different levels. It would be convenient to describe this correspondence in the reverse order:

- as has been said before, the totalitarianism vs. non-totalitarianism opposition was taken into consideration by choosing at least one non-totalitarian country (United States of America) as a backdrop 
for discussing the totalitarian societies (Soviet Union and Nazi Germany);

- the first-person vs. third-person opposition was addressed by choosing two kinds of discursive evidence as far as performance of power was concerned. For the self-references to political leadership, a sample of political speeches for the period between 1936 and 1943 was selected (Hitler 1935, 1938, 1941, 1942; Stalin 1937a, 1937b, 1941, 1942, 1943; Roosevelt 1936a, 1936b, 1936c, 1936d, 1936e, 1941, 1942a, 1942b, 1943). ${ }^{2}$ In its turn, the other-references to political leadership were studied on the material of the major newspapers in three countries (Völkischer Beobachter, Pravda and The New York Times) for the first three months of 1936 (first pages only).

- the differentiation between egocentricity vs. objectivity was in part overlapping with the previous opposition-but only in part: it is clear that Roosevelt could refer to himself both in the first (' $I$ ') and in the third ('President') person, but for his followers only the latter option was possible. Therefore this differentiation was studied separately from the previous one on the material of the leaders' speeches.

- Lastly, the narration vs. performance dichotomy was incorporated by the sharp distinction between the narrative descriptions' of Stalin, Hitler and Roosevelt's "activity" and "omnipresence" (summarized above) and the grammatical manifestations of these properties (presented below in the Tables 1-4). The grammatical definition of "omnipresence" was straightforward and purely qualitative: the more references to a particular leader were found in respective texts, the more "present" in a public culture he was considered to be. The grammatical correlate or "activity" was somewhat more complex, consisting of two functional definitions-being a subject and being a subject to an object, so that the sentences ' $I$ ga $v e$ a

2 | For each leader, an approximate volume of 1000 sentences was analyzed. Since beginnings, middles and ends of political speeches show very different frequencies of self-referential statements-see, for example, the Hitler figures in Ulonska (1990: 123)-the slight inequalities in the number of sentences (928 for Hitler, 1022 for Stalin, 1101 for Roosevelt) were considered to be lesser evil than the fragmentation of sentences. The problem of choosing the proportional and homogeneous samples was exacerbated by the fact that Stalin's talks were few and Roosevelt's addresses tended to be very short. 
talk' (in leader's speech) or 'Hit le r was at the reception' (in a newspaper report) would attest to the leader activity, whereas the sentences 'The reception was in my prese $n c e$ ' (in leader's speech), 'The talk was given by Stalin' (in a newspaper report), 'Stalin's talk was greeted with ovation' (in a newspaper report) and ' $M y$ participation in the reception is important' (in leader's speech) would not. ${ }^{3}$

The impossibility of maintaining a ratio "one opposition-one table" is evident, since the different levels of language are represented by the same words, sentences and communication acts that cannot be just torn apart or divided into layers. Because of that, each table has a double identity-it incorporates one of the dichotomies discussed above and at the same time constitutes a half of another dichotomy (together, all the tables present performance as opposed to narration). Having this difficulty in mind, I formulated questions to each of the tables so that the oppositions between the tables and inside the tables would be clearly set apart:

1. How often do the respective leaders refer to themselves as objective power structures ('President', 'Chancellor', 'Secretary General' etc.) as opposed to others as objective power structures ('Government', 'Parliament', 'Court', 'Party', 'People' etc.)? (Table 1)

2. How often do the respective leaders refer to themselves as the individual ego-centers of discursive performance ('I' ' me'/'my') as opposed to the collective ego-centers of discursive performance ('We' / 'us' / 'our')? (Table 2)

3. How often do the respective leaders refer to themselves as egocentric power structures_agents ('I did...'/'we are...'), bystanders ('to me,...'/'for us,...'), or possessors ('my country...' / 'our land...')? (Table 3)

4. How often do the others refer to their political leaders as objective power structures - agents ('Hitler gave a talk'), bystanders ('Greetings to Stalin'), or possessors ('Roosevelt's speech')? (Table 4)

3 | I have deliberately chosen six sentences, describing just two states of affairs* Stalin giving a talk and *Hitler being at a reception. The contrast between the situations' factual similarity and their varying discursive realization underscores the differences between the communicative setting (which provides the inventory of codes) and the actual interaction (which produces social power). 
The following interpretations of the Tables come to mind:

\section{Table 1-2 (“Omnipresence”)}

Contrary to expectations, Stalin's presence in his own discourse appears to be much less pronounced than Hitler's or Roosevelt's in theirs: there are positively no "objective" references and a very few "egocentric" references to his own discourse. Hitler, by contrast, demonstrates the highest and most stable level of presence in his own discourse both as a third-person (be it 'Chancellor', 'Leader of the Nation' or 'Head of the Government') and as a first-person ('I'). Roosevelt's figures are more changeable - as has been noticed before, his first-person references to self noticeably decline during the war (Hinckley 1990: 124). However, from the purely quantitative standpoint, the self-presentation of Roosevelt in his own discourse is much closer to Hitler's than to Stalin's. Overall, all the three leaders, for natural linguistic reasons, prefer "egocentric" mode of selfreference to the "objective" one, and their adherence to the high (Roosevelt, Hitler) or low (Stalin) profile is consistent across both modes of orientation.

\section{Table 3-4 ("Activity")}

The distribution of the performative roles of the three leaders in the public discourse shows the many of the same tendencies and groupings as the Tables 1-2: again, Stalin stands out as the least "active" of the three leaders, whereas Hitler's "activity" level is more constant than Roosevelt's throughout both periods of observation. At the same time, two noteworthy differences separate the results in the Tables 3-4 from the previous data. On the one hand, in the pair Hitler-Roosevelt, Roosevelt stands as the more active leader both in self- and in other-references. On the other hand, Stalin's "activity" figures are not as consistently low across the communicative roles as his "omnipresence" figures: one could say that the image of a very "inactive" (and very "possessive") leader is much more manifest in Stalin's own texts than in the newspaper reports, whereas neither Roosevelt nor Hitler figures reveal similar discrepancy between their self- and other-references to "activity". 


\section{Table 1-4}

On the whole, the results presented in the tables seem to put into question the preconceptions about the interwar political leadership formulated on the narrative basis. Firstly, the narrative of power and its actual discursive performance may be at variance: Hitler's hyperactive self- and other-presentation in public discourse is consistent with the myth of his "activity" circulated in Nazi narratives about Fuhrer, but Roosevelt's even more conspicuous activeness has no similarly evident narrative shadow. Secondly, the link between the rigid control of mass media in a totalitarian society and the maximization of the leader's presence in public discourse appears to be problematic in both directions - totalitarianism may exist without a strong individualist discourse of its leader, and vice versa. Indeed, the highest "activity" and "presence" figures characterizing the discursive performance of a political leader are split between totalitarian Nazi Germany and non-totalitarian United States of America, while Stalin's leadership, seen through the prism of Soviet public discourse, is highly ambivalent: in his own speeches Soviet leader appears rarely, in a markedly passive and non-individualistic role, but in the newspapers (and possibly in other public media as well)he is shown to be quite visible and even moderately active.

As the first discussion of the Tables 1-4 mostly challenges the simplified views of the totalitarian leadership by offering empirical counterevidence, it inevitable produces more questions than answers. How to explain similarities between the discursive performance of leadership in Nazi Germany and Roosevelt's America, and why such an obvious gap between the self-and the other-performance of leadership in Stalinist Russia? More specifically, how two so-called "personality cults" engendered two diametrically opposed systems of leaders' self-reference in public - one based on redundancy of 'egocentric' and 'objective' selfreferences (Hitler) and another on their demonstrable scarcity (Stalin)?

Unless the numbers presented above are accidental or unreliable, their absolute or relational similarities should point at some social affinities between the countries of Hitler and Roosevelt. In fact, many such affinities (at different levels) have been already noticed by the wartime scholars (White 1949), although structuring these likenesses has rarely been trouble-free. The most superficial resemblance (directly related to the numbers above) was the fact that both political leaders had been 
significantly more self-centered in their political discourses than any of their predecessors in the respective countries (Winckler 1970: 32-36; Hinckley 1990: 109-112). What's more, Roosevelt was also head and shoulders above his precursors in dominating the public sphere: for instance, the frequency with which his name appeared on the front page of American newspapers was for his country unprecedented (Dawis 1987: 25). Unlike German dictator and Soviet tyrant, the American president had at his disposal only indirect means of media control (Keller 1995: 154; for Stalin's laborious image management see: Davies 2004), one can assume that the noticeable symmetry between self-reference and other-reference in Roosevelt's political discourse was not a product of administrative regulation from above, but rather reflected the specificity of President's political performance.

What remains unclear, though, is the level at which this specificity is being generated. Some studies derived Roosevelt's omnipresence in the media a from the egocentricity of his 1936 presidential campaign which succeeded in profiling the incumbent's self as the major part of his message ('Democratic program' = 'first and foremost Roosevelt's personality') and reduced the plurality of choices to the single contradictory opposition (presidential election = 'voting for Roosevelt' vs. 'voting against Roosevelt') (White 1949: 173; Crowell 1950: 48-49). Other scholars see the affinity at a deeper level, pointing at Roosevelt's unparalleled and often unconstitutional use of direct presidential action such as executive orders, presidential messages to Congress, appointments by decrees and vetoes: in 1930s alone, Roosevelt vetoed 505 measures passed by Congress, which was $30 \%$ of all the vetoes since the beginnings of American presidency (Dawis 1987: 24-25; Cooper 2002: 40; Howell 2003: 6; Schivelbusch 2005: 23-24, 40). Given these proportions, it is hardly surprising that the similarities between Roosevelt's New Deal, Mussolini's fascism, Hitler's National Socialism and Stalin's Bolshevism were widely (and sometimes sympathetically) discussed in all the respective countries, except for Soviet Union (Schivelbusch 2005: 25-30).

It is impossible to deny that Roosevelt's power performance was at variance with many norms, traditions and discursive practices of democratic leadership: the fact that the President's name and activity were at the center of media attention throughout his term, reveals not only Roosevelt's self-centered model of political campaigning, but also his egocentric praxis of government. But it would be a gross and useless simplification to call his presidency "totalitarian", or to ascribe "totalitarianism” to American political system of the 1930s-1940s. Individualism 
and obsessive self-referentiality of the leader's discursive performance undeniably attests to the authoritarian tendencies of the social system, but could hardly be its major indicator: Indeed, Stalin's discursive performance of power was clearly not individualistic, but his public image and executive style were: for most of his tenure, Soviet dictator was prone to micro-management and distrusted any collective body or selfconscious social group (see: Werth 1999: 40; Ennker 1996: 117; Gill 1980: 171; Khlevniuk 2005: 117). Since it is evidently impossible to establish a simple one-to-one correspondence between the reflexivity of the leader's public discourse and the self-centeredness of his managerial activity (see: Tosi 1982: 224), it seems practical to subject to a more elaborate analysis both hypostases of public power performance, and compare their interrelations in every case. The distinction, including the breakdown to subcategories, could be presented in the following way:

- In terms of social performance (1), all the three chief executives could be called charismatic rulers, each willing - albeit to a different degree-to stake his mantle of the prophet against traditions and laws (Weber 1920: 140-143). However, charismatic leadership in modern society is usually intertwined with bureaucratic and (less often) patriarchal power performance, and its stability is unthinkable without some stabilization-Weber's Veralltäglichungby means of tradition or law (institutions).

- From the standpoint of organizational management (2), Stalin, Hitler and Roosevelt played in their respective countries the role of transformational leaders: highly visible among their followers, they all claimed possession of the great "visions" unachievable without followers' sacrifices, and were prone to use the chain of command to speed up the arrival of the happy future (Burns 1978: 121; Kirkpatrick and Locke 1996: 45; Tosi 1982: 225). Nevertheless, as the pure execution of power is only possible in the case of absolute, transcendental legitimacy (like Divine rule), transformational leadership style is inevitably combined with transactional one, based on leader's communicative exchanges and bargains with followers (Howell and Hall-Merenda 1999: 681).

Obviously, not only the two major objectives of power performance may be at odds with each other in every single case of political leadership, but even within the categories the performance may be inconsistent, varying between different forms, media and areas of interaction. This 
inconsistency is particularly striking in Stalinist Russia (where self- and other-references to the leader are so much unalike), but it may also come to surface in two other countries if one looks closer at their interactional norms and organizational properties.

\section{Stalin (1): Charismatic Leadership (with some Elements of Traditionalism) and its Bureaucratic Stabilization}

Stalin's charismatic rule was undoubtedly the most radical assault on traditions and institutions, as its formative part consisted of progressive usurpation of power at different levels. At first, Bolsheviks came to power in an anti-monarchic coup d'état as a tiny group in a broad coalition of political forces, but managed to force out the majority by means of terror (see, for example: Fitzpatrick 2008: 49-68). Later on, the same kind of power monopolization occurred on personal level: being just one of several dozen Bolsheviks close to Lenin-he unquestionable leader of the party and Head of State in 1917-1922-Stalin cunningly and ruthlessly forced himself into a position of his only heir, having gradually stifled or exterminated all the competitors (see, for instance: Ulam 1989: 234-286). Unsurprisingly, the charismatic leadership of Stalin was from the outset complicated by restrictions and incongruities. The paradoxical nature of his inherited charisma - messianic communism taken over from Lenin who, in his turn, adopted it from Karl Marx — made it difficult for Stalin to prioritize his prophetic role (Thompson 1988: 103). Besides, the tendency to treat Lenin as a communist Messiah was already apparent in 1918, after the assassination attempt on his life (Ovsiannkov 1992: 188; Tumarkin 1997: 81). Unwilling to take a risk of removing the figure of Lenin from the center of Bolshevik ideology, the party oligarchy after some hesitation has opted for the construction of the curious "twin cult" of a dead and a living ruler which stressed the hereditary nature of greatness ('Stalin is Lenin of our time') (Gill 1980: 169; Rees 2004: 9; Harris 2005: 75). ${ }^{4}$ For that purpose, a laborious effort of retroactively inventing the new "myth of the creation" ('Stalin as a leader of Bolshevik revolu-

4 | On the importance of double portraits of Lenin-Stalin at this period see: Sartorti 1995: 196. In the Nazi performance of power, the streamlining of leadership performance and leadership discourse took place in 1934 following the death of German president Paul von Hindenburg and the murder of Hitler's only potential rival, Ernst Roehm (Mommsen 1981: 43). In the Triumph of Will (1935)-the famous staged documentary of Leni Riefenstahl—the Fuhrer was the only protagonist (Dolezel and Loiperberger 1995: 84-88). 
tion') was launched around 1929, Stalin's 50 ${ }^{\text {th }}$ anniversary (Ovsiannkov 1992: 200; Ennker 1996: 94; Suny 1997: 39; Ennker 2004: 85). Besides, the strong rationalist tendencies of Marxism, retained by Bolshevik ideology and rhetoric (Widmer 1987: 74; Sedov 1989: 441; Rees 2004: 16), prevented Stalin from assuming the role of an individual mystagogue, although his trumped-up status of the "coryphaeus of all sciences"-a sort of Robespierre's Culte de la Raison come alive-was in many ways a simple translation of this role into non-mystical terms (Pollock 2006: 1). Lastly, the strong collectivist pathos of Bolshevik rhetoric precluded abolition of collective bodies within Party and State, although their role and size during Stalin's rule was steadily diminishing (Werth 1999: 39; Ennker 1996: 108, 116).

The role of tradition in Stalin's discursive performance of leadership was limited to transmitting charismatic power from the earlier leader of Bolshevism - any other kind of traditionalism would have inevitably compromised the revolutionary nature of Bolshevik teleology. On the other hand, the active role of ordinary citizens in the Marxist ideology made their purely passive, shadowy representation in Stalin's power discourse as unlikely as the opposition between the hyper-active leader and the passive environment, so prevalent in Hitler's discursive selfperformance (Andrain 1972: 201). In fact, the speeches of Soviet leader are full of tautological litanies to "masses". ${ }^{5}$ Given these differences between respective ideological environments, it seems natural that Stalin and his milieu opted for the bureaucratic routinization of charismatic leadership (Weber 1920: 143; Kofler 1970: 39; Kershaw 1994: 38; Ennker 1996: 102; Kershaw and Lewin 1997: 21; Rees 2004: 3) which had no immediate relation to tradition and entailed no 'hero-worship' (in Thomas Carlyle's terms). ${ }^{6}$ That said, at certain periods of cult formation and transformation Stalin could not resist the populist temptation to boost his leadership by demonizing "bureaucracy" (Werth 1999: 42; Ennker 1996: 102). But the direct expression of Stalin's leadership in political discourse occurred mostly in the field of other-reference, where other scenarios of power stabilization were tried-for instance, the patriarchal one ('Stalin, our beloved father... [teacher... ]') (see: Sartorti 1995: 204; Günther 1997; Ennker 2004: 90; Walker 2004: 58). It should be

5 | "We should not, if for a single minute, weaken our bonds with masses" (Stalin 1937b: 226).

6 | On the other hand, the cult of Duce, clearly focused upon the personality of Benito Mussolini, recycled the preexisting bureaucratic structures of the Italian state (Bach 1990). 
noted, however, that both in Stalin's own discourse and in the media, bureaucratic tendency prevailed. Whereas Hitler's forms of discursive selfand other-performance reflected his neo-romantic, anti-institutional stance, legitimated primarily by metahistorical ordo ordonans and only conditionally by his followers' approval (Galtung 1987: 52, 54), Stalin's individuality was seen in a Soviet discourse more as an alternative institution (such as 'universal authorship' or 'national fatherhood') than as a personal self (Inkeles 1962: 25; Tucker 1992: 31), although from the middle of 1930s this institutional roles were somewhat personalized (Ennker 1996: 106). In this circuitous way, Stalin's political supremacy was reconciled with his negative self-positioning in his own discourse (Tucker 1972: 146; Fairhurst 2007: 109-110; for the similar dialectics in Lenin's discursive performance of power see: Ovsiannkov 1992: 192).

\section{Hitler (1): Charismatic Leadership (with some Remainders of Legal Power) and its Traditionalist Stabilization}

In contrast to Stalin, Hitler's charismatic rule was from its very beginning full of prophetic self-fashioning and anti-traditionalist pathos, but its break with the institutional power was late and gradual. In a way typical for messianic ideologies, the political demand for a Savior coming from afar existed before the major candidates have shown up (Cohn 1970: 281-286): for instance, such Northern European ideologues as Hendrik de Man or Ernst Junger expressed their yearning for Fuhrer long before Hitler became well-known figure (see, for instance: Lepsius 1986: 56-57; Kershaw 1987: 13). Although Hitler first tried to fulfill these expectations in a Beer Hall Putsch of 1923, he came to power a decade later in a democratic election which gave his party an undisputed majority (Kershaw 1994: 34; Bessel 1995: 16), and it took the Nazi leader another three years to adjust his self-performance to the mystical cult created around his personality by Goebbels and other propagandists (Gruchmann 1973: 188; Kershaw 1987: 82; Dolezel and Loiperdinger 1995: 86). At the same time German Chancellor little by little took away the legal and (to a lesser extent) the traditional foundations of his rule, having taken away the legislative powers of Reichstag and institutionalized his party nickname (Fuhrer) as an official title (Rebentisch 1989: 44; Bessel 1995: 22).

Hitler opted for charismatic leadership as a means to eliminate cyclical, competitive and impersonal character of power in a democratic society which presented a direct threat to direct fulfillment of a radical 
teleology. The tendency to style state power as a personal Self, purified of all institutional objectifications (Lepsius 1986: 60), is manifest not only in Hitler's general scenarios of power performance, such as aversion to any written, formalized, "bureaucratic" forms of power execution (Gruchmann 1973: 198; Paterson 1981: 439; Rebentisch 1989: 29), but also on the low levels of his public discourse: in this vein, his taking the personal oath of allegiance from the Armed Forces (Burrin 1999: 57) corresponds to saturation of political speeches with unusually intimate self-characterizations ("my brain”, "my sensations", "my patience” etc. (Hitler 1941: 104, 108; Hitler 1938: 3)). If the unrestrained individuality of supreme political will was intended in Hitler's Germany to serve as a $s u b$ ject of power performance (Rebentisch 1989: 37), then its predicate was seen in the ultimate objectivity of the Laws of Nature and History (Arendt 1958: 474, 477). In this vein, the elimination of agens in repetitive passive constructions (It is clear to all that...) - together with pervasive nominalization (Mo b i l i z a t i o $n$ goes forward...)-serves as a backdrop for the Fuhrer's solitary Ich (Voigt 1978: 287-288; Winckler 1970: 42; Bork 1970: 47; Maas 1989: 173). In its turn, this “objectification” of political discourse serves as a precondition for the dialectical self-overcoming of charismatic leadership_its routinization (Weber 1920: 143). To be sure, Stalin (or, for that matter, Benito Mussolini or Nikolae Ceauşescu) also practiced in his public discourse nominalization and passive constructions for the very same purpose (Ilie 1998; Danler 2006; Weiss 1995: 344). However, as the mechanisms of this routinization were not quite the same, their linguistic expression varied accordingly. In Hitler's texts, "tradition" the abundance of lexical, morphological and syntactic archaisms suggest traditional roots of the charismatic power, aimed at securing the latter's stability in the absence of institutional or legal mechanisms of power performance (see: Berning 1962: 71, 116; Bork 1970: 260; Weiss 1986: 288; Rees 2004: 16), whereas the same stabilization function in Stalin's public discourse is performed by bureaucratic vocabulary and syntax (Weiss 1994: 384).

\section{Roosevelt (1): Legal Leadership (with some Elements of Charismatic Power) and its Internal Stability (Relational and Conditional)}

Roosevelt's charismatic rule is the most problematic of all the three since none of its major components is as strong, explicit or personalized as 
in the two previous cases. Indeed, the American president's challenges to the institutional order, while being serious, did not go far beyond the conventional populist means: the flood of executive orders, vetoes and presidential decrees hampered Congress and de facto introduced the state of emergency in economics, but neither words nor other actions of the President hinted at replacement of Constitution or regular elections with another source of personal legitimacy (Schivelbusch 2005: 40, 65). Without a doubt, Roosevelt was not above using old or introducing the new techniques of modern communication which granted to the leader communicative supremacy at the expense of the audience: like Hitler and Stalin, he was tireless in training his voice, rehearsing his speeches and also the first in his office to deliver them via radio (Ulonska 1990; Dawis 1987: 4; Bessel 1995: 18; Schivelbusch 2005: 56-58;). What's more, with his office Roosevelt inherited the spiritualistic individualism of American presidential discourse, centered upon the divine blessing of the Nation and-eo ipso-its sole leader (Hinckley 1990: 131-133). However, Roosevelt's use of these performative techniques, typical for charismatic leadership (Kirkpatrick and Locke 1996: 38), was clearly subordinate to the legal framework of American presidency. As a populist, he frequently resorted to some of the gadgets of charismatic leadership in order to highlight his closeness to the "people" and the distance from "bureaucracy", but even his own political discourse contests this opposition: in the texts analyzed in Tables 1-4, references to 'Government' eclipse the references to 'American people' in all texts except the two last war addresses. Roosevelt's self-legitimation through voice, eloquence and medial accessibility was conditional and temporary; it worked only insofar as the president's basic legitimacy was confirmed by the last popular election and enacted by existing administrative structures.

\section{Stalin (2): Transformational leadership with some elements of transactional leadership}

The earlier discussion of political leadership seemed to confirm its interactional nature: apparently, no leader, king or president, can reign without habitual legitimation, provided in a dialogue with followers inlands and peers abroad (van Dijk 1988: 256; Barker 2001: 83). However, the erosion of political representation in totalitarian states causes irregularity of legitimation procedures. Monopolization of communicative chances inevitably leads to the breakup of feedback chains between 
ruler and the followers, and the gap between the imagined and real constituency grows as fast as their real difference blurs: the interaction with the inner circle of advisers becomes indistinguishable from the mass demonstration. This over-projection of self-reference into other-reference breeds withdrawal, delusion and paranoia-the states in which political fictions, produced for propagandist use, take the place of observation and analysis: Stalin's suspicion that the member of his inner circle, the half-literate Marshal Clement Voroshilov was the British agent, is the case in point (Tucker 1992: 41-44). This grotesque example illustrates the dead end of purely transformational leadership, cut off from any legitimating exchanges with followers, and points at its potential threat to organizational stability: small wonder that even the cowardly and complacent Bolshevik establishment at the end sabotaged such paranoid actions of Soviet leader as zealous extermination of peasantry in 1929-1930 or the mass terror of 1937-1938 (Ennker 1996: 95). But for the most part of Stalin's rule, the relation between the transformational core and the transactional periphery of his power was somewhat more stable and regular. The general public was a priori excluded from any kind of spontaneous political communication and relegated to the role of statists at staged other-references to the leader. Whereas secret police (directly supervised by Stalin) prevented ordinary citizens from any spontaneous contact with the leader, the latter, in turn, was prohibited from walking the streets (the decision issued by Politburo on Stalin's own initiative (Werth 1999: 42, 44; Khlevniuk 2005: 111). As for the transactional basis of Stalin's leadership, it was expectedly formed around the small size, high-level bureaucratic structures, such as Secretariat and Special office of the Bolshevik Party Central Committee (Ennker 1996: 107; Ennker 2004: 169; Harris 2005: 64). The line between the transformational chain of command and transactional bargaining ground was drawn arbitrarily: while the actual discussions with uncertain outcome usually took place between Stalin and his trusted advisers and holders of various government posts, such as Viacheslav Molotov (Skriabin), Lazar Kaganovitch or Klement Voroshilov, the other Secretariat members were in most cases "asked" to stamp the decision post factum and pass it over to the larger collective bodies-such as Politburo or Central Committee itself-for institutionalization and ceremonial confirmation (Werth 1999: 39; Khlevniuk 1996: 83; Ennker 2004: 178; Getty 2005: 86, 99; Khlevniuk 2005: 110). 


\section{Hitler (2): Transformational leadership with some elements of transactional leadership}

The functional equivalent of Stalin's paranoia was Hitler's mania grandiosa. Supported by fuzzy logic of official propaganda (which referred to Nazi leader as the 'will' of their 'action'), and obedient legal theory (which treated law as the simple codification of the Fuhrer's Wille-Giaro 1999: 249), the Fuhrer came to believe that his volition was indeed a source of national power (Vondung 1979: 398). The fact that this lunacy was not stopped until it thoroughly destroyed the state foundations speaks for the extreme weakness of the transactional mechanisms in the system of political leadership. Some barriers that Hitler erected between himself and his followers were reminiscent of Stalin's measures (such as complete disappearance from public sphere in 1942, explained away by excessive workload (Kershaw 1987: 121; Volmert 1989: 139; Bohse 1988: 127)). But Hitler was much more consistent than Stalin in purging spontaneous political bargaining from the public communication: in the last ten years of his political career, the German leader not only increasingly detached himself from everyday political business but also steadfastly demolished all remaining areas of transactional politics such as collective bodies or councils: in fact, governance was reduced to Hitler's personal orders given to 100 highest officers and four bureaucratic bodies, all vying for the Fuhrer's attention (Nyomarkay 1967: 145; Gruchmann 1973: 192; Neumann 1977; Mommsen 1981: 59; Kershaw 1985: 73, 84; Burrin 1999: 63-64; Overy 2004: 111-113). The inefficiency and arbitrariness of such leadership was obvious, but, in all probability, the economical and political failings of transformational leadership with little transactional elements were seen by Hitler (and Stalin) as tolerable side-effects of this system of power representation, compared to its relatively stable performative advantages (Howell 1999: 683, 690).

\section{Roosevelt (2): Transactional leadership with some elements of transformational leadership}

If totalitarian conventions of power performance inherited from European monarchies the clear division between the transcendental competence of the individual rulers and the purely instrumental function of their followers, the founders of American nation saw the whole nation the subject of messianic accomplishment. Accordingly, the strength 
of the country's highest office was derived not from the leader's visionary intuition communicated to and approved by ordinary citizens, but from his ability to successfully bargain for his objectives with as many citizens as possible,. Indeed, the classical treatise of Richard Neustadt, widely seen as an apology of strong executive power of Rooseveltian kind, equates presidential strength with negotiating successes: using communicative preferences of executive power, the president should be able to persuade others that their social interests are best served by fulfilling his political goals (Neustadt 1960). Unmistakable in Roosevelt's presidential addresses, this distinctive combination of transformational messianism with transactional activity brings to light the crucial difference between his and Hitler's self-performance of political power. Neither American president nor Nazi leader shy away from portraying themselves as prophets, although Hitler ('I have often happened to be a prophet in my life') feels more comfortable in this role than Roosevelt (' $M$ M] prophecy is in the process of being fulfilled') (Hitler 1941: 103; Roosevelt 1943: 329). At the same time, Hitler's speeches were characterized by a monological structure typical for orations ('Here I am a speaker of the whole German nation'), while Roosevelt frequently inserted into his addresses the second-person references to his listeners ('You and I know now...'), having earned from John Dos Passos the derisive title of "youand-me president" (Hitler 1938: 1; Roosevelt 1936b: 162; Schivelbusch 2005: 58-59). As much as the subject-predicate scheme employed by Hitler embodied his unidirectional approach to political communication discussed above (higher wisdom communicated by leader to his all-to-human subjects), Roosevelt's inclusion of listeners into his master narrative signaled the consensual nature of his message perfected in numerous interactions with his followers.

It looks like the association of totalitarian leaders with activity and omnipresence in its simple form cannot be confirmed or disproved by empirical data: the very same reference to leaders (such as pronouns ' We' or ' $m y$ ', or proper names 'Stalin') may have very different meanings depending on communicative environments, ideological conventions or organizational principles, and cannot serve as unambiguous correlates of this or that performative strategy. The attempt to get rid of one-dimensional characterization of political discourse prevalent in its narratological interpretations, resulted in a more compound explanation of data on 'activity' and 'omnipresence' of leaders in Soviet Union, Nazi Germany and United States in 1936-1943.

For example, Stalin's first-person reticence, juxtaposed with the bac- 
chanalia of third-person references to him in media, clearly attests to the disparity of collectivist ideology and individualist power system in Soviet Union. In any transparent public sphere such a blatant discrepancy would damage the credibility of official doctrine or-inversely—put into question the sincerity of "popular support", but such external evaluations (abundant in the West), were seen by Stalin as lesser evil than moving the shaky foundations of his historical and popular legitimacies). But the very same scarcity of demonstrative pronouns ' $I$ ' and ' $w e$ ' in Stalin's public discourse, projected onto the relative abundance of possessive pronouns (' $m y$ ' and 'our') in the very same texts and similar constructions in the media ('Stalin's words'), points at a different property of Stalin's discursive performance of power-the necessity of the leader canonization, which stems not only from the general tendency to routinization of charismatic leadership, but also from the questionable legitimacy of his own power. The fact the leader is portrayed in his own discourse and public media more as a depository of invaluable knowledge ('Stalin's wise instructions') than an agent of history seems to be an important part of this canonizing effort which deserves to be studied in more detail (for the relevant insights see: Tucker 1972: 157; Brandenberger 2005: 251).

Another double juxtaposition could better explain the policemy of the leaders' first-person references as indicators of political and organizational conditions. The similar ratios 'activity'/'possession' in firstand other-references to Roosevelt and Stalin in public discourse (Tables 3-4) hints at the likeness of the two leaders' discursive performance of power but the comparative analysis of their state management reveals profound difference between the monological ' $I$ ' of the transformational leader, used in orders and revelations ('I', and the dialogical 'I' of the transactional leader, employed in a context of narrative equality (' $I$ and you'). Furthermore, as the unflinching egocentricity of Hitler's firstperson public discourse and its extension into the sphere of the personal (see above) could be explained by progressive deinstitutionalization of power in charismatic leadership, Roosevelt's interactional stance is surely linked to the role-taking nature of democratic politics which sees first-person statements of a ruler as a mere tool of political bargaining from the position of power. Again, the exact room taken in Roosevelt's speeches by this rhetorical figure of 'conversation partner' has yet to be studied in depth. To sum up, Roosevelt's discursive space of power could be compared to a perennial construction site, whereas the fitting alle- 
gories for Hitler's and Stalin's power performance by means of language would respectively be a stadium and a mausoleum.

Table 1: Third-person-references to specific power structures in the leaders' texts $(100 \%=$ all references to power structures in a given text $)$

\begin{tabular}{|c|c|c|c|c|c|c|c|}
\hline & & 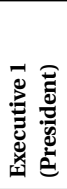 & 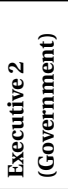 & 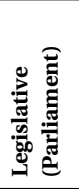 & 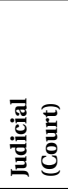 & 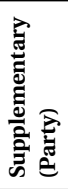 & 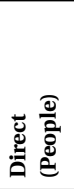 \\
\hline 1 & 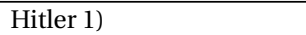 & 13.7 & 21.6 & 7.9 & 0.0 & 3.9 & 52.9 \\
\hline 2 & Hitler 2) & 16.7 & 0.0 & 8.3 & 0.0 & 0.0 & 75.0 \\
\hline 3 & Hitler Pre-War 1)+2) & 14.4 & 17.5 & 7.9 & 0.0 & 3.3 & 57.1 \\
\hline 4 & Hitler 3) & 33.3 & 0.0 & 0.0 & 0.0 & 16.7 & 50.0 \\
\hline 5 & Hitler 4) & 0.0 & 0.0 & 0.0 & 0.0 & 0.0 & 100.0 \\
\hline 6 & Hitler Wartime 3)+4) & 26.7 & 0.0 & 0.0 & 0.0 & 13.3 & 60.0 \\
\hline 7 & Hitler Total 1)+2)+3)+4) & 11.7 & 19.5 & 6.5 & 0.0 & 5.2 & 57.1 \\
\hline 8 & Stalin 5) & 0.0 & 27.0 & 0.0 & 0.0 & 71.4 & 1.6 \\
\hline 9 & Stalin 6) & 0.0 & 21.7 & 0.0 & 0.0 & 73.6 & 4.7 \\
\hline 10 & Stalin Pre-War 5)+6) & 0.0 & 23.7 & 0.0 & 0.0 & 72.8 & 3.6 \\
\hline 11 & Stalin 7) & 0.0 & 0.0 & 0.0 & 0.0 & 0.0 & 100.0 \\
\hline 12 & Stalin 8) & 0.0 & 55.6 & 0.0 & 0.0 & 44.4 & 0.0 \\
\hline 13 & Stalin 9) & 0.0 & 4.5 & 0.0 & 0.0 & 31.9 & 63.6 \\
\hline 14 & Stalin Wartime 7)+8)+9) & 0.0 & 16.2 & 0.0 & 0.0 & 29.7 & 54.1 \\
\hline 15 & Stalin Total 5)+6+7)+8)+9) & 0.0 & 22.4 & 0.0 & 0.0 & 65.0 & 12.6 \\
\hline 16 & Roosevelt 10) & 13.3 & 23.3 & 53.3 & 0.0 & & 10.0 \\
\hline 17 & Roosevelt 11) & 0.0 & 10.0 & 0.0 & 0.0 & & 0.0 \\
\hline 18 & Roosevelt 12) & 0.0 & 78.6 & 12.5 & 0.0 & & 0.0 \\
\hline 19 & Roosevelt 13) & 0.0 & 87.5 & 12.5 & 0.0 & & 0.0 \\
\hline 20 & Roosevelt 14) & 27.2 & 45.4 & 9.0 & 0.0 & & 18.2 \\
\hline 21 & $10)+11)+12)+13)+14)$ & 9.0 & 56.4 & 24.3 & 1.3 & & 9.0 \\
\hline 22 & Roosevelt 15) & 28.6 & 28.6 & 42.8 & 0.0 & & 0.0 \\
\hline 23 & Roosevelt 16) & 0.0 & 50.0 & 30.0 & 0.0 & & 20.0 \\
\hline 24 & Roosevelt 17) & 0.0 & 20.0 & 20.0 & 0.0 & & 60.0 \\
\hline 25 & Roosevelt 18) & 0.0 & 0.0 & 0.0 & 0.0 & & 100.0 \\
\hline 26 & 15)+16)+17)+18) & 7.7 & 30.8 & 26.9 & 0.0 & & 34.6 \\
\hline 27 & $\begin{array}{l}10)+11)+12)+13)+14) \\
+15)+16)+17)+18)\end{array}$ & 8.6 & 52.0 & 25.0 & 1.0 & & 15.4 \\
\hline
\end{tabular}


Table 2: Singular vs. plural self-references in leaders' texts (in \%)

\begin{tabular}{|c|c|c|c|}
\hline & Texts & I-Me-My & We-Us-Our \\
\hline 1 & 1) Hitler 1935 & 45.2 & 54.8 \\
\hline 2 & 2) Hitler 1938 & 69.8 & 30.2 \\
\hline 3 & Hitler Pre-War 1)+2) & 48.5 & 52.8 \\
\hline 4 & 3) Hitler 1941 & 47.2 & 52.8 \\
\hline 5 & 4) Hitler 1942 & 56.5 & 43.5 \\
\hline 6 & Hitler Wartime 3)+4) & 48.3 & 51.7 \\
\hline 7 & 5) Stalin 1937a & 3.6 & 96.4 \\
\hline 8 & 6) Stalin 1937b & 11.8 & 88.2 \\
\hline 9 & Stalin Pre-War 5)+6) & 6.1 & 93.1 \\
\hline 10 & 7) Stalin 1941 & 2.1 & 97.9 \\
\hline 11 & 8) Stalin 1942 & 7.8 & 92.2 \\
\hline 12 & 9) Stalin 1943 & 1.6 & 98.4 \\
\hline 13 & Stalin Wartime 7)+8)+9) & 3.8 & 96.2 \\
\hline 14 & 10) Roosevelt 1936a & 39.8 & 60.2 \\
\hline 15 & 11) Roosevelt 1936b & 37.7 & 62.3 \\
\hline 16 & 12) Roosevelt 1936c & 37.1 & 62.9 \\
\hline 17 & 13) Roosevelt 1936d & 23.4 & 76.6 \\
\hline 18 & 14) Roosevelt 1936e & 42.6 & 57.4 \\
\hline 19 & Roosevelt Pre-War & 37.1 & 62.9 \\
\hline 20 & 10)+11)+12)+13)+14) & & 81.5 \\
\hline 21 & 15) Roosevelt 1941 & 18.5 & 92.3 \\
\hline 22 & 16) Roosevelt 1942a & 7.7 & 84.1 \\
\hline 23 & 17) Roosevelt 1942b & 15.9 & 83.2 \\
\hline 24 & 18) Roosevelt 1943 & 26.8 & \\
\hline & & 15.0 & \\
\hline
\end{tabular}


Table 3: Activity, presence and posession:

three forms of grammatical self-references in the leaders speeches $(100 \%=$ all reflexive statements in a given text $)$

\begin{tabular}{|c|c|c|c|c|}
\hline & Texts & $\begin{array}{r}\text { Activity } \\
{[\mathrm{I}-W e]} \\
(I \text { think...) } \\
\end{array}$ & $\begin{array}{r}\text { Presence } \\
\text { [Me-Us] } \\
\text { (it was said to } m e \text { ) }\end{array}$ & $\begin{array}{r}\text { Possession } \\
\text { [My-Our] } \\
\text { (our mission) }\end{array}$ \\
\hline 1 & 1) Hitler 1935 & 60.4 & 16.5 & 23.1 \\
\hline 2 & 2) Hitler 1938 & 68.2 & 11.1 & 20.6 \\
\hline 3 & Hitler Pre-War 1)+2) & 62.0 & 15.4 & 22.6 \\
\hline 4 & 3) Hitler 1941 & 64.2 & 13.7 & 22.1 \\
\hline 5 & 4) Hitler 1942 & 37.0 & 28.2 & 34.8 \\
\hline 6 & Hitler Wartime 3)+4) & 61.4 & 15.0 & 23.6 \\
\hline 7 & 5) Stalin 1937a & 17.2 & 16.4 & 66.4 \\
\hline 8 & 6) Stalin 1937b & 26.9 & 16.1 & 57.0 \\
\hline 9 & Stalin Pre-War 5)+6) & 21.0 & 16.3 & 62.7 \\
\hline 10 & 7) Stalin 1941 & 14.4 & 10.3 & 75.3 \\
\hline 11 & 8) Stalin 1942 & 22.1 & 13.0 & 64.9 \\
\hline 12 & 9) Stalin 1943 & 16.1 & 9.7 & 74.2 \\
\hline 13 & Stalin Wartime 7)+8)+9) & 17.4 & 11.0 & 71.6 \\
\hline 14 & 10) Roosevelt 1936a & 86.4 & 3.4 & 10.2 \\
\hline 15 & 11) Roosevelt 1936b & 83.0 & 1.9 & 15.1 \\
\hline 16 & 12) Roosevelt 1936c & 56.5 & 12.9 & 30.6 \\
\hline 17 & 13) Roosevelt 1936d & 57.9 & 18.7 & 23.4 \\
\hline 18 & 14) Roosevelt 1936e & 78.8 & 9.2 & 12.0 \\
\hline 19 & $\begin{array}{l}\text { Roosevelt Pre-War } \\
(10)+11)+12)+13)+14)\end{array}$ & 73.8 & 9.1 & 17.1 \\
\hline 20 & 15) Roosevelt 1941 & 55.6 & 12.9 & 31.5 \\
\hline 21 & 16) Roosevelt 1942a & 58.1 & 11.1 & 30.8 \\
\hline 22 & 17) Roosevelt 1942b & 63.0 & 7.3 & 29.7 \\
\hline 23 & 18) Roosevelt 1943 & 68.3 & 7.3 & 24.4 \\
\hline 24 & Roosevelt Wartime17)+18)+19) & 60.0 & 10.0 & 30.0 \\
\hline
\end{tabular}

Table 4: Activity, presence and posession: three syntactic forms of reference to the leaders

\begin{tabular}{|c|c|c|c|c|c|}
\hline & Texts & $\begin{array}{c}\text { Activity } \\
\text { Hitler gave a talk }\end{array}$ & $\begin{array}{c}\text { Presence } \\
\text { Greetings to Stalin }\end{array}$ & $\begin{array}{c}\text { Possession } \\
\text { Roosevelt's speech }\end{array}$ & $\begin{array}{c}\text { Total } \\
(\mathbf{1 0 0 \% )}\end{array}$ \\
\hline 1 & Roosevelt & $556(59.9 \%)$ & $140(15.0 \%)$ & $234(25.1 \%)$ & 930 \\
\hline 2 & Stalin & $237(30.5 \%)$ & $224(28.8 \%)$ & $317(40.7 \%)$ & 778 \\
\hline 3 & Hitler & $308(43.0 \%)$ & $175(24.4 \%)$ & $233(32.5 \%)$ & 716 \\
\hline
\end{tabular}

Source: Völkischer Beobachter 1936 January-March (Hitler); Pravda 1936 January-March (Stalin); New York Times 1936 January-March (Roosevelt). 


\section{References \\ Primary Sources}

Hitler, A. 1935. Rede des Führers und Reichskanzlers Adolf Hitler vor dem Reichstag am 21. Mai 1935. Berlin: Zentralverlag des NSDAP.

Hitler, A. 1938. Rede im Berliner Sportpalast. In NS-Archiv. Dokumente zum Nationalsozialismus. www.ns-archiv.de/krieg/1938/ tschechoslowakei/wollen-keine/tschechen.php

Hitler, A. [1941] 1943. Rede vor dem alten Garde. In Der Grossdeutsche Freiheitskampf. Band III. Reden Adolf Hitlers vom 16. März 1941 bis 15. März 1942, by A. Hitler, 89-109. München: Zentralverlag der NSDAP.

Hitler, A. [1942] 1943. Aufruf an Partei und Volk (31. Dezember 1941).In Der Grossdeutsche Freiheitskampf. Band III. Reden Adolf Hitlers vom 16. März 1941 bis 15. März 1942, by A. Hitler, 159-166. München: Zentralverlag des NSDAP.

Roosevelt, F. D. [1936a] 1957. Annual Message to the Congress (January $3^{\text {rd }}$, 1936). In The Roosevelt Reader, edited by B. Rauch. New York: Rinehart.

Roosevelt, F. D [1936b] 1957. Address to the Young Democratic Club (April 13 ${ }^{\text {th }}$, 1936). In The Roosevelt Reader, edited by B. Rauch. New York: Rinehart.

Roosevelt, F. D. [1936c] 1957. Address at Little Rock, AR (June 10 ${ }^{\text {th }}, 1936$ ). In The Roosevelt Reader, edited by B. Rauch. New York: Rinehart.

Roosevelt F. D. [1936d] 1957. Acceptance of the Renomination for the Presidency at Philadelphia. PA (June $27^{\text {th }}, 1936$ ). In The Roosevelt Reader, edited by B. Rauch, 69-74. New York: Rinehart.

Roosevelt, F. D. [1936e] 1957. Franklin D. Roosevelt. Address at Chautauqua, NY (August 14 ${ }^{\text {th }}$, 1936). In The Roosevelt Reader, edited by B. Rauch. New York: Rinehart.

Roosevelt, F. D. [1941] 1970. Address over the Radio Following the Declaration of a State of War with the Japanese Empire (December $9^{\text {th }}$, 1941). In Development of the U.S. Foreign Policy. Addresses and Messages, by F. D. Roosevelt. New York: Kraus Reprints.

Roosevelt, F. D. [1942a] 1970. Address of the President of the United States delivered Before a Joint Session of the Two Houses of Congress (January $6^{\text {th }}, 1942$ ). In Development of the U.S. Foreign Policy. Addresses and Messages, by F. D. Roosevelt. New York: Kraus Reprints. Roosevelt, F. D. [1942b] 1970. Address over the Radio in celebration of Washington's Birthday (February $\left.23^{\text {rd }}, 1942\right)$. In Development of the 
U.S. Foreign Policy. Addresses and Messages, by F. D. Roosevelt. New York: Kraus Reprints.

Roosevelt, F. D. [1943] 1970. Radio Address on War and Peace Plans, July $28^{\text {th }}, 1943$. In Development of the U.S. Foreign Policy. Addresses and Messages, by F. D. Roosevelt, 329-333. New York: Kraus Reprint.

Stalin, J. V. [1937a] 1997. О недостатках партийной работы и мерах ликвидаџии троџкистских и иных двурушников. Доклад на Пленуме ЏК ВКП (б) марта 1937 года. Б Собрание сочинений. Том 15, И. В. Сталин. Москва: Писатель.

Stalin, J. V. [1937b] 1997. Заключительное слово на Пленуме ЏК ВКП (б) 5 марта 1937 года. Б Собрание сочинений. Том 15, И. В. Сталин. Москва: Писатель.

Stalin, J. V. [1941] 1997. Доклад на торжественном заседании Московского совета депутатов трудящихся с партийными и общественным организаџиями города Москвы 6 ноября 1941 года. Б Собрание сочинений. Том 15, И. В. Сталин. Москва: Писатель.

Stalin, J. V. [1942] 1997. Доклад на торжественном заседании Московского совета депутатов трудящихся с партийными и общественным организаџиями города Москвы 6 ноября 1942 года. Б Собрание сочинений. Том 15, И. В. Сталин. Москва: Писатель.

Stalin, J. V. [1943] 2007. Доклад на торжественном заседании Московского совета депутатов трудящихся с партийными и общественным организаџиями города Москвы 6 ноября 1943 года. Б Собрание сочинений. Том 15, И. В. Сталин. Москва: Писатель.

\section{Secondary Sources}

Alekseev, G. 1982. Количественные параметры культа личности. In CCCP. Внутренние противоречия, Выпуск 6: 5-10.

Austin, J. L. 1962. How to Do Things with Words. London: Oxford University Press.

Andrain, C. F. 1972. Political Life and Social Change. An Introduction to Political Science. Belmont: Duxberry Press.

Arendt, H. 1958. On Revolution. New York: Viking Press.

Bach, M. 1990. Die charismatischen Führerdiktaturen. Drittes Reich und italienischer Faschismus im Vergleich ihrer Herrschaftsstrukturen. Baden-Baden: Nomos-Verlagsgesellschaft. 
Barbu, Z. 1953. Language in Democratic and Totalitarian Societies. A Psychological Interpretation. Orbis. Bulletin International de Documentation Linguistique 2 (1): 73-81.

Barker, R. 2001. Legitimating Identities. The Self-Presentation of Rulers and Subjects. Cambridge: Cambridge University Press.

Berning, C. 1962. Die Sprache des Nationalsozialismus. Zeitschrift für die deutsche Wortforschung 18: 108-118.

Berning, C. 1964. Vom "Abstammungsnachweis" zum "Zuchtwart". Vokabular des Nationalsozialismus. Berlin: de Gruyter.

Bessel, R. 1995. Charismatisches Führertum? Hitlers Image in der deutschen Bevölkerun. In Führerbilder. Hitler, Mussolini, Roosevelt, Stalin in Fotografie und Film, edited by M. Loiperdinger, R. Herz and U. Pohlmann, 14-26. München: Piper.

Betz, W. 1955. The National-Socialist Vocabulary. In The Third Reich, edited by M. Beaumont, J. Fried and E. Vermeil, 710-741. New York: Praeger.

Bohse, J. 1988. Inszenierte Kriegsbegeisterung und ohnmächtiger Friedenswille. Meinungslenkung und Propaganda im Nationalsozialismus. Stuttgart: Metzler.

Bolz, D. 2008. Les arénes totalitaires. Fascisme, nazisme et propaganda sportive. Paris: CNRS Editions.

Bork, S. 1970. Missbrauch der Sprache. Tendenzen nationalsozialistischer Sprachregelung. Bern: Francke.

Bosmajian, H. 1960. The Nazi Speaker's Rhetoric. Quarterly Journal of Speech 46 (1-4): 307-318.

Bosmajan, H. 1966. The Magic Word in Nazi Persuasion. ETC. A Review of General Semantics 23 (1): 9-23.

Brackmann, K.-H. 1988. NS-Deutsch. Selbstverständliche Begriffe und Schlagwörter aus der Zeit des Nationalsozialismus. Straelen: Straelener Manuskripte-Verlag.

Brandenberger, D. 2005. Stalin as Symbol. A Case Study of the Personality Cult and Its Construction. In Stalin. A New History, edited by S. Davies and J. Harris, 249-270. Cambridge: Cambridge University Press.

Burrin, P. 1999. Charisma and Radicalism in the Nazi Regime. In Stalinism and Nazism. History and Memory Compared, edited by $\mathrm{H}$. Rousso and R. J. Golsan, 56-70. Omaha: University of Nebraska Press.

Burns, J. 1978. Leadership. New York: Harper Row.

Cavalli, L. 1986. Charismatic Domination, Totalitarian Leadership, and 
Plebiscitary Democracy in the Twentieth Century. In Changing Conceptions of Leadership, edited by C. F. Graumann and S. Moscovici, 67-81. New York: Springer.

Crowell, L. 1950. Franklin D. Roosevelt's Audience Persuasion in the 1936 Campaign. Speech Monographs 17 (3): 48-63.

Culbert, D. 1995. Franklin D. Roosevelt. Das Image des "demokratischen” Führers in Wochenschau und Radio. In Führerbilder. Hitler, Mussolini, Roosevelt, Stalin in Fotografie und Film, edited by M. Loiperdinger, R. Herz and U. Pohlmann, 166-188. München: Piper. Danler, P. 2006. "Parlarle senza dirlo" or "Speaking without Saying It". The Diathetically Conditioned Deletion of Complements as a Rhetorical Device', Journal of Language and Politics 5 (3): 305-354.

Davies, S. 1997. Popular Opinion in Stalin's Russia. Terror, Propaganda and Dissent, 1934-1941. Cambridge: Cambride University Press.

Davies, S. 2004. Stalin and the Making of the Leader Cult in the 1930s. In The Leader Cult in Communist Dictatorships. Stalin and the Eastern Bloc, edited by B. Apor et al., 29-46. Basingstoke: Palgrave Macmillan.

Dawis, J. 1987. The American Presidency. Baltimore: Johns Hopkins University Press.

Dijk, T. van. 1988. Ideology. A Multidisciplinary Approach. London: Sage.

Dolezel, S. and M. Loiperdinger (editors). 1995. Führerbilder. Hitler, Mussolini, Roosevelt, Stalin in Fotografie und Film. München: Piper. Elias, N. 1983. Die höfische Gesellschaft. Frankfurt am Main: Suhrkamp. Ennker, B. 1996. Terroristische Diktaturen im 20. Jahrhundert. Strukturelemente der nationalistischen und stalinistischen Herrschaft. Oppladen: Westdeutscher Verlag.

Ennker, B. 2004. The Stalin Cult, Bolshevik Rule and Kremlin Interaction in the 1930s. In The Leader Cult in Communist Dictatorships. Stalin and the Eastern Bloc, edited by B. Apor et al., 83-101. Basingstoke: Palgrave Macmilla.

Fairhurst, G. 2007. Discursive Leadership. In Conversation with Leadership Psychology. Thousand Oaks: Sage.

Falasca-Zamponi, S. 2004. The "Culture" of Personality. Mussolini and the Cinematic Imagination. In Personality Cults in Stalinism, edited by K. Heller and J. Plamper, 83-107. Göttingen: Vandenhoeck \& Ruprecht.

Faye, J.-P. 1987. Corps social et languages face à l'Etat totalitaire. In Forces et fiablesses des totalitarismes, edited by E. Morin, 63-71. Fribourg. 
Fitzpatrick, S. 2008. The Russian Revolution. Oxford: Oxford University Press.

Friedberg, M. 1962. Russian Classics in Soviet Jackets. New York: Columbia University Press.

Galtung, J. 1987. Hitlerismus, Stalinismus, Reaganismus. 3 Variationen zu einem Thema von Orwell. Baden-Baden: Nomos.

Getty, J. A. 2005. Stalin as Prime Minister. Power and the Politburo. In Stalin. A New History, edited by S. Davies and J. Harris, 83-107. Cambridge: Cambridge University Press.

Giaro, T. 1999. Aufstieg und Niedergang des sozialistischen Zivilrechts. Von der Ideologie zur Rechtsdogmatik der Pauschalenteignung. In Recht im Sozialismus. Band 1. Enteignung, edited by G. Bender and U. Falk, 217-297. Frankfurt am Main: Klostermann.

Gill, G. 1980. The Soviet Leader Cult. Reflections on the Structure of Leadership in the Soviet Union. British Journal of Political Science 10 (2): 167-186.

Gruchmann, L. 1995. Die Reichsregierung im Führerstaat. Stellung und Funktion des Kabinetts im national-sozialistichen Herrschaftssystem. In Führerbilder. Hitler, Mussolini, Roosevelt, Stalin in Fotografie und Film, edited by M. Loiperdinger, R. Herz and U. Pohlmann, 187-223. München: Piper.

Günther, H. 1997. Wise Father Stalin and his Family in Soviet Cinema. In Socialist Realism Without Shores, edited by T. Lahusen and E. Dobrenko, 178-190. Durham and London: Duke University Press.

Hale, O. 1965. Presse in der Zwangsjacke. 1933-1945. Düsseldorf: Droste. Harris, J. 2005. Stalin as General Secretary. The Appointments Process and the Nature of Stalin's Power. In Stalin. A New History, edited by S. Davies and J. Harris, 63-82. Cambridge: Cambridge University Press.

Herz, R. 1995. Vom Medienstar zum propagandistischen Problemfall. $\mathrm{Zu}$ den Hitlerbildern Heinrich Hoffmans. In Führerbilder. Hitler, Mussolini, Roosevelt, Stalin in Fotografie und Film, edited by M. Loiperdinger, R. Herz and U. Pohlmann, 51-64. München: Piper.

Hinckley, B. 1990. The Symbolic Presidency. How Presidents Portray Themselves. New York: Routledge.

Hopkins, M. 1970. Mass Media in the Soviet Union. New York: Pegasus. Howell, M., K. E. Halle-Merenda and E. Kathryn. 1999. The Ties That Bind. The Impact of Leader-Member Exchange, Transformational and Transactional Leadership, and Distance of Predicting Follower Performance. Journal of Applied Psychology 84 (5): 680-694. 
Howell, W. 2003. Power without Persuasion. The Politics of Direct Presidential Action. Princeton: Princeton University Press.

Ilie, C. 1998. The Ideological remapping of Semantic Roles in Totalitarian Discourse, or, How to Paint White Roses Red. Discourse and Society 9 (1): 57-80.

Inkeles, A. 1962. Public Opinion in Soviet Russia. A Study in Mass Persuasion. Cambridge: Cambridge University Press.

Keller, U. 1995. Franklin D. Roosevelts Bildpropaganda im historischen und systematischen Vergleich. In Führerbilder. Hitler, Mussolini, Roosevelt, Stalin in Fotografie und Film, edited by M. Loiperdinger, R. Herz and U. Pohlmann, 135-165. München: Piper.

Kershaw, I. 1985. The Nazi Dictatorship. Problems and Perspectives of Interpretation. London: Arnold.

Kershaw, I. 1987. The "Hitler Myth". Image and Reality in the Third Reich. Oxford: Oxford University Press.

Kershaw, I. 1994. Totalitarianism Revisited. Nazism and Stalinism in Comparative Perspective. Tel Aviver Jahrbuch für deutsche Geschichte 23: 23-40.

Kershaw, I. 1997. Working Towards the Führer. Reflections on the Nature of the Hitler Dictatorship. In Stalinism and Nazism. Dictatorships in Comparison, edited by I. Kershaw and M. Lewin, 88-106. Cambridge: Cambridge University Press.

Kershaw I. and M. Lewin. 1997. Introduction. The regimes and Their Dictators. Perspectives of Comparison. In emphStalinism and Nazism. Dictatorships in Comparison, edited by I. Kershaw and M. Lewin, 1-25. Cambridge: Cambridge University Press.

Khlevniuk, O. 1996. Политбюро. Механизмы политической власти в 30-е годы. Москва: Росспен.

Khlevniuk, O. 2005. Stalin as Dictator: The Personalization of Power. In Stalin. A New History, edited by S. Davies and J. Harris, 108-120. Cambridge: Cambridge University Press.

Kirkpatrick, S. and E. Locke. 1996. Direct and Indirect Effects of Three Core Charismatic leadership Components on Performance and Attitudes. Journal of Applied Psychology 81 (1): 36-51.

Kofler, L. 1970. Stalinismus und Bürokratie. Zwei Aufsätze. Neuwied: Luchterhand.

Lambertson, F.W. 1942. Hitler, the Orator. A Study in Mob Psychology.

The Quarterly Journal of Speech 28 (2): 123-131.

Lazar, A. and Lazar M. 2004. The Discourse of the New World Order. 
Out-Casting' the Double Face of Threat. Discourse and Society 15 (2-3): 223-242.

Lepsius, M. 1986. Charismatic Leadership. Max Weber's Model and its Applicability to the Rule of Hitler. In Changing Conceptions of Leadership, edited by C. F. Graumann and S. Moscovici, 52-66. New York: Springer.

Maas, U. 1989. Sprache im Nationalsozialsmus. Analyse einer Rede eines Studentenfunktionärs. In Sprache im Faschismus, edited by K. Enlich, 162-197. Frankfurt am Main: Suhrkamp.

Minnerup, W. 1989. Pressesprache und Machtergreifung am Beispiel der Berliner Germania. In Sprache im Faschismus, edited by K. Enlich, 198-235. Frankfurt am Main: Suhrkamp.

Moltman, G. 1964. Goebbels Rede zum totalen Krieg am 18. Februar 1943. Vierteljahrshefte für Zeitgeschichte 12: 13-45.

Mommsen, H. 1981. Hitlers Stellung im nationalsozialistischen Herrschaftssystem. In Der Führerstaat. Mythos und Realität, edited by G. Hirschfeld and L. Kettenacker, 43-69. Stuttgart: Klett-Cotta.

Neumann, F. 1977. Behemoth. Struktur und Praxis des Nationalsozialismus 1933-1944. Köln: Europäische Verlagsanstalt.

Neustadt, R. 1960. Presidential Power. New York: Wiley.

Nyomarkay, J. 1967. Charisma and Factionalism in the Nazi Party. Minneapolis: University of Minnesota Press.

Overy, R. (2004) The Dictators. Hitler's Germany and Stalin's Russia. New York: Allen Lane.

Ovsiannikov, A. 1992. Истоки вождизма. Идеология И практика. In Формирование адиминистративно-командной системы. 20-е-30-е годы. Москва: Наука.

Peterson, E. 1969. The Limits of Hitler's Power. Princeton: Princeton University Press.

Plamper, J. 2003. The Spatial Politics of the Personality Cult. Circles around Stalin. In The Landscape of Stalinism. The Art and Ideology of Soviet Space, edited by E. Dobrenko and E. Naiman, 19-50. Seattle: University of Washington Press.

Rebentisch, D. 1989. Führerstaat und Verwaltung im Zweiten Weltkrieg. Verfassungsenwicklung und Verwaltungspolitik 1939-1945. Stuttgart: Steiner.

Rees, E. 2004. Leader Cults. Varieties, Preconditions and Functions. In The Leader Cult in Communist Dictatorships. Stalin and the Eastern Bloc, edited by B. Apor et al., 3-28. Basingstoke: Palgrave Macmillan. Rigby, T. 1977. Stalinism and the Mono-Organizational Society. In Stal- 
inism. Essays in Historical Interpretation, edited by R. C. Tucker, 53-76. Toronto: University of Toronto Press.

Riley, R. L. 2000. The Limits of the Transformational Presidency. In Presidential Power. Forging the Presidency for the Twenty-first Century, edited by R. Y. Shapiro, M. J. Kumar and L. R. Jacobs, 434-455. New York: Columbia University Press.

Rolf, M. 2004. Working Toward the Centre. Leader Cults and Spatial Politics in Pre-War Stalinism. In The Leader Cult in Communist Dictatorships. Stalin and the Eastern Bloc, edited by B. Apor et al., 141-157. Basingstoke: Palgrave Macmillan.

Sack, R. 1986. Human Territoriality. Its Theory and History. Cambridge: Cambridge University Press.

Sartori, R. 1995. Grosser Führer, Lehrer, Freund und Vater. Stalin in der Fotografie. In Führerbilder. Hitler, Mussolini, Roosevelt, Stalin in Fotografie und Film, edited by M. Loiperdinger, R. Herz and U. Pohlmann, 189-209. München: Piper.

Schivelbusch, W. 2005. Entfernte Verwandschaft. Faschismus, Nationalsozialismus, The New Deal (1933-1939). München: Carl Hanser Verlag.

Sedov, L. 1989. И жреџ, и жнеџ. . К вопросу о корнях культа вождя. In Осмыслить культ Сталина. Москва: Прогресс.

Suny, R. 1997. Stalin and His Stalinism. Power and Authority in the Soviet Union, 1930-1953. Stalinism and Nazism. Dictatorships in Comparison, edited by I. Kershaw and M. Lewin, 26-52. Cambridge: Cambridge University Press.

Thompson, R. 1988. Reassessing the Personality Cults. The Cases of Stalin an Mao. Studies in Comparative Communism 21 (1): 99-128.

Tosi, H. 1982. Commentary on Part 3. Toward a Paradigm Shift in the Study of Leadership, In Leadership. Beyond Established Views, edited by J. G. Hunt, U. Sekaran and C. A. Schriesheim, 222-233. Carbondale: Southern Illinois University Press.

Tucker, R. 1972. The Soviet Political Mind. Stalinism and Post-Stalin Change. New York: Allen and Unwin.

Tucker, R. .1992. Stalin in Power. The Revolution From Above 1928-1941. New York: Norton.

Tumarkin, N. 1997. Ленин жив! Культ Ленина в Спвецкой Руссии. Санкт-Петербург: Академический проект.

Ulam, A. .1989. Stalin. The Man and His Era. London: Allen Lane. Ulonska, U. 1990. Suggestion der Glaubwürdigkeit. Untersuchungen 
zu Hitlers rhetorischer Selbstdarstellung zwischen 1920 und 1933. Ammersbek bei Hamburg: Verlag an der Lottbek Jensen.

Voigt, G. 1978. Faschistische Rede? Zu Stilistik und Rezeption des Aufrufs A. Hitlers vom 19. 12. 1941. In Sprache in Gegenwart und Geschichte. Festschrift für Heinrich Matthias Heinrichs zum 65. Geburtstag, edited by D. Hartmann, H. Linke and O. Ludwig, 281-293. Köln: Böhlau.

Voigt, G. 1987. Das Wortfeld als Instrument der Analyse. Untersuchung eines nationalsozialistischen Wahlaufrufes vom 1.3.1932. Praxis Deutsch 14 (85): 62-64.

Volmert, J. 1989. Politische Rhetorik des Nationalsozialismus. In Sprache im Faschismus, edited by K. Ehlich, 137-161. Frankfurt am Main: Suhrkamp.

Vondung, K. 1979. Spiritual Revolution and Magic. Speculation and Political Action in National Socialism. Modern Age 23 (4): 394-402. Walker, B. 2004. Iosif Stalin, “Oure Teacher Dear”. Mentorship, Social Transformation and the Russian Intelligentsia Personality Cult. In Personality Cults in Stalinism, edited by K. Heller and J. Plamper, 45-60. Göttingen: Vandenhoeck \& Ruprecht.

Weber, M. [1920] 1972. Wirtschaft und Gesellschaft. Tübingen: Mohr. Weiss, D. 1985. Was ist neu am "Newspeak” Reflexionen zur Sprache. In Slavistische Linguistik 1985. Referate des XI. Konstanzer Slavistischen Arbeitstreffens, edited by R. Rathmayr, 247-325. München: Otto Sagner.

Weiss, D. 1995. Prolegomena zur Geschichte der verbalen Propaganda in der Sowjetunion. In Slavistische Linguistik 1994. Referate des XX. Konstanzer Slavistischen Arbeitstreffens, edited by D. Weiss, 343-391. München: Otto Sagner.

Weiss, D. 2000. Alle vs. Einer. Zur Scheidung von good guys and bad guys in der sowjetischen Propagandasprache. In Slavistische Linguistik 1999. Referate des XXV. Konstanzer Slavistischen Arbeitstreffens, edited by W. Breu, 237-275. München: Otto Sagner.

Weiss, D. 2002. Personalstile im Sowjetsystem? Stalin und Chruščev im Vergleich. In: Wege der Kommunikation in der Geschichte Osteuropas, edited by N. Boskovska, P. Collmer and S. Gilly, 223-252. Köln: Böhlau.

Weiss, D. 2003. Stalinistischer und nationalsozialistischer Propagandadiskurs im Vergleich: eine erste Annäherung. In Slavistische Linguistik 2001. Referate des XXVII. Konstanzer Slavistischen Arbeit- 
streffens, edited by G. Freidhof and H. Kuße, 309-357. München: Otto Sagner.

Weiss, D. 2005. Stalinist vs. Fascist Propaganda. How Much Do They Have In Common? In Manipulation and Ideologies in the Twentieth Century, edited by L. de Saussure and P. Schulz, 251-274. Amsterdam: Rodopi.

Werth, N. 1999. Stalin's System during the 1930s. In Stalinism and Nazism. History and Memory Compared, edited by H. Rousso and R. J. Golsan, 29-55. Omaha: University of Nebraska Press.

White, R. 1949. Hitler, Roosevelt and the Nature of War Propaganda. Journal of Abnormal and Social Psychology 44: 157-174.

Widmer, J. 1987. Aspects langagiers des totalitarismes. In Forces et faiblesses des totalitarismes. Les actes du IVe colloque sur les totalitarismes, edited by P. Meyer-Bisch, 73-84. Fribourg: Editions Universitaires.

Winckler, L. 1970. Studien zur gesellschaftlichen Funktion faschistischer Sprache. Frankfurt am Main: Suhrkamp.

Wodak, R. 2006. Doing Politics. The Discursive Construction of Politics. Journal of Language and Politics 5 (3): 299-303.

Young, J. 1991. Totalitarian Language. Orwell's Newspeak and its Nazi and Communist Antecedents. Charlottesville: University of North Carolina Press. 
